\title{
Dam Break Analysis and Inundation Mapping, Case Study of Fincha'a Dam in Horro Guduru Wollega Zone, Oromia Region, Ethiopia
}

\author{
Jiregna Nugusa Duressa, Asie Kemal Jubir \\ Department of Hydraulic Engineering, Addis Ababa University, Addis Ababa, Ethiopia \\ Email address: \\ jnyonata@gmail.com(J.N.Duressa),asie@gmail.com(A. K. Jubir)
}

\section{To cite this article:}

Jiregna Nugusa Duressa, Asie Kemal Jubir. Dam Break Analysis and Inundation Mapping, Case Study of Fincha'a Dam in Horro Guduru Wollega Zone, Oromia Region, Ethiopia. Science Research. Vol. 6, No. 2, 2018, pp. 29-38. doi: 10.11648/j.sr.20180602.11

Received: October 23, 2017; Accepted: December 18, 2017; Published: April 26, 2018

\begin{abstract}
Fincha'a Dam was constructed in 1973 for the purpose of electricity generation, irrigation, fishery and truism with $22.2 \mathrm{~m}$ height and $340 \mathrm{~m}$ crest length. Fincha'a dam is rock fill dam with uncontrolled over flow spillway. There are different economic developments downstream of the Fincha'a dam including hydropower pant, irrigation project, residential house and sugar factory. These economic developments are affected either dam break by overtopping or piping mode of failure. The calculated breach parameters by Von Thun and Gillette Regression equation are selected as input data into the HEC-RAS model for dam break analysis. The general objective of the study is to analyze Dam break by using hydraulic models (Hydraulic Engineering Center's River Analysis system). For this study the failure location is assumed to be at the center of the dam due to presence of high hydrostatic pressure and develop equally in both sides. From the result of Fincha'a dam break simulation the peak discharge formed by overtopping mode of failure is more devastating than the piping mode of failure. The effect of dam breach parameters on discharge is more pronounced than that of the water level. Dam break has greater impact on the downstream location where is closer to the dam in accordance with the hydrograph at downstream locations. The created Fincha'a river network was exported to HEC-RAS model for further dam break analysis by addition of different geometric data including dam information, calculated breach parameters, initial condition, upstream and downstream unsteady boundary condition. After full computation the model result were exported to integrated Arc-GIS and HEC- GeoRAS model for mapping flood inundation. Developed inundation map guides the dam owners and emergency management authority to give emergency action plan for the highly affected area by flooding and used for planning future economic development activities.
\end{abstract}

Keywords: Dam Break, Analysis, HEC-RAS, Hydrograph, HEC-GeoRAS, Inundation

\section{Introduction}

Dams have been constructed for thousands of years around the world for different purposes: flood control, electricity generation, irrigation, water supply, recreation and etc (21). But also, hundreds of dams have failed due to high flows in the river, sea, etc. In India the worst dam disaster occurred in Machhu II dam was constructed to serve an irrigation scheme (10). This dam failed because of excess flood, inadequate capacity of spillway and due to overtopping of water over embankment dam in August 1, 1979. Kaddam Dam was failed due to overtopping of water above the crest by $46 \mathrm{~cm}$ and due to this mode of failure $137.2 \mathrm{~m}$ of breach width has been developed on the left bank in August 1958 (1). The world's worst dam failure like Banqiao Dam and the Shimantan Dam occurred due to the overtopping in August 1975 and around 85,000 peoples were died by flooding in China (15). Simulation of dam break result and resulting floods are essential for characterizing and reducing negative effects occurred on the downstream area. Development of emergency action plan requires exact estimation of inundation level and the arrival time of flood wave at the downstream point. The breakage frequencies of earth dams are almost four times greater than concrete dams or masonries (17).

Dam failure results due to external force and internal erosion. The United State Army corps of Engineering Hydrologic Engineering center (HEC) research document lists 13 dam failure causes as: 1) earth quake 2) land slide 3) 
extreme storm 4) piping 5) equipment malfunctioning 6) structure Damage 7) foundation failure and Sabotage and etc (23). Breach is defined as the opening formed in the dam body that causes the water to spread to the downstream location (23). Different Case studies show that dam failure may arise due to different reasons ranging from seepage, piping (internal erosion), overtopping due to insufficient free board and settlement due to side slopes on the upstream shells and liquifaction due to earthquakes.

Piping is a flow of water in porous parts of the dam especially through high permeability regions, cavities, fissures or strata of sand and gravel. Such concentrated flow at hydraulic gradient may erode the soil part of the dam which causes the breakage of the earth dam. Piping through the dam body is caused by: faulty construction, insufficient compaction, cracks in the embankment due to foundation settlement, animal borrows pipes and conduits inside the dam body.

Overtopping is defined as uncontrolled flow of water over the crest of the dam. Overtopping may lead to failure of the dam due to excessive erosion of downstream slope. The main causes of overtopping are: under estimation of the design flood and inadequate spillway capacity, large and rapid landslides in the reservoir, insufficient free board and malfunctioning of the spillway gates. The three primary tasks in Dam Break Analysis are: estimation of dam break out flow hydrograph, routing of dam break hydrograph through downstream valley, estimation of inundation levels and damages to downstream structures. Many models have been developed before few years for dam break analysis such as DAMBRK, FLDWAV, SMPDBK, and HEC-RAS Model etc (2).

\subsection{Statement of the Problem}

Dam break can result in huge damages to downstream areas of the dam. Embankment dam breach may be caused by overtopping or piping mode of failure. Fincha'a dam will cross the Fincha'a River between two basalt abutments. Due to construction of Fincha'a dam, more than 3,115 households were resettled downstream of the dam near to the river Fincha'a dam is rock fill dam, which was constructed by Impresit Rechi contractor, Italy. There are different economic developments downstream of the Fincha'a dam such as hydropower plant, irrigation project, residential house and sugar factory; these activities can be affected if the dam breaks (18). In 1987 Amarti dam is constructed and diverted to Fincha'a reservoir which dramatically increased the number of resettled people.

There is probable loss of human lives, houses, buildings and other interest economic activities if dam failure occurs. The outer coverage of Fincha'a dam is rock shell from the upstream and downstream sides of the dam and its core part is constructed from impervious earth and there is transition zone between internal and outer part of the dam. Therefore, we have to give deep attention for breaking of embankment dams; because floods resulting from the dam breach produce huge damages to the downstream areas. Since Fincha'a dam is embankment dam there is probability of occurrence of dam break due to overtopping and internal erosion.

\subsection{Objective of the Research Study}

\subsubsection{General Objective}

The general objective of the study is to analyze the Dam break case study of Fincha'a dam using hydraulic models.

\subsubsection{Specific Objectives}

1. To determine parameters of the dam break;

2. To determine peak outflow hydrograph when dam break occurs by either overtopping or piping mode of failure;

3. To estimate the hydraulic conditions (water level, top width and arrival time of flood wave) at critical downstream locations and

4. To inundate flood-prone areas of downstream area due to dam failure.

\section{Research Methodology}

\subsection{Study Area}

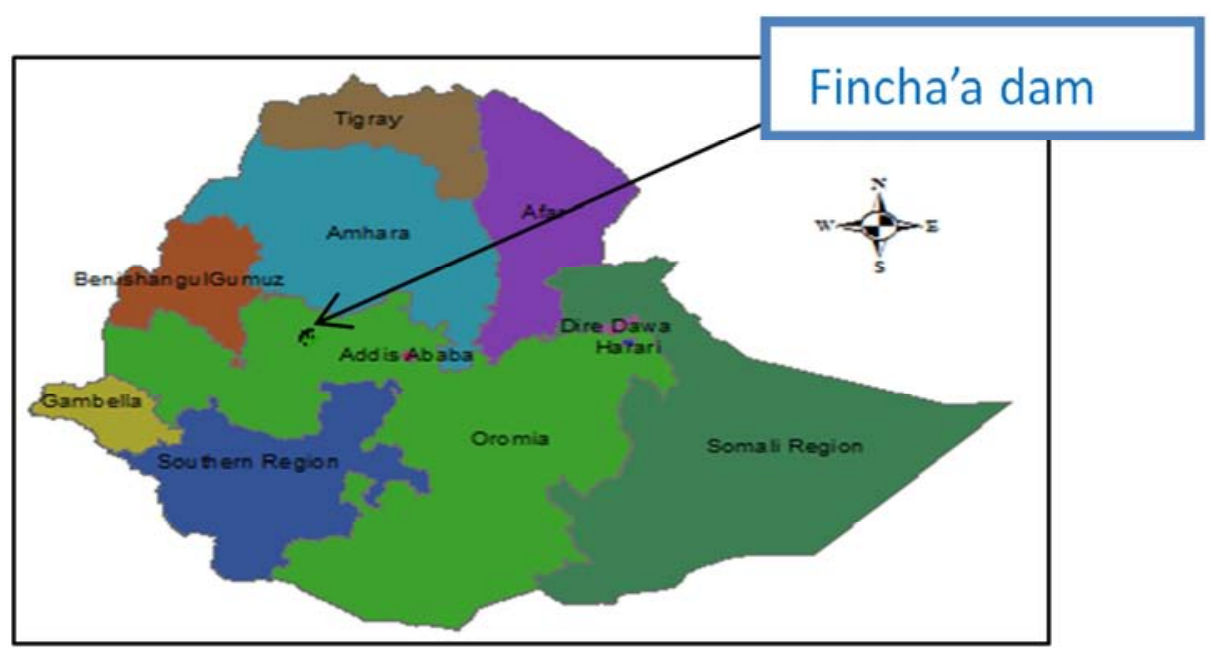

Figure 1. Map of the research study area. 
The Fincha'a dam is Rock fill dam and which is constructed on a plateau creating a Reservoir with volume of $406 \mathrm{Mm}^{3}$ at a full reservoir level of elevation 2220m (m.a.s.l) in 1973. Providing an additional storage capacity of about $219 \mathrm{Mm}^{3}$ through tunnel from Amarti diversion project, the total storage capacity of the Reservoir becomes $625 \mathrm{Mm}^{3}$ at elevation of $2222 \mathrm{~m}$ (m.a.s.l).

\subsection{Motheds of Dam Break Analysis}

The most commonly used methods to determine the required breach elements for dam break analysis are: Comparative analysis, Empirical methods, Physically- based models, and parametric models. For this thesis study empirical methods and hydraulic models are used for the dam break analysis. Hydraulic model (HEC-RAS) is characterized under parametric models and the most commonly used for steady and unsteady flow analysis.

\subsubsection{Hydraulic Model (HEC-RAS)}

HEC-RAS (Hydraulic Engineering Center's River Analysis System) is free downloadable software which was developed by Hydrologic Engineering Center of the U.S. Army Corps of Engineering. It is public domain and an integrated system of software, designed for interactive use multitasking use in the environment. The system is comprised of a graphical user interface (GUI), separate analysis components, data storage and management capabilities, graphics and reporting facilities. The HEC-RAS System contains four one dimensional river analysis components: steady flow water surface computations, unsteady flow simulation, movable boundary sediment transport computation, and water quality analysis. A key element is that all four components use a common geometric data representation and hydraulic computation routine.

The main objective of HEC-RAS Model is to compute water surface elevation at all location of interest for either a given set of flow data (steady flow simulation) or by routing hydrographs through the system (unsteady flow simulation). It is used to model both overtopping and piping failure breaches for embankment dam. The data needed for these computations are divided into the following categories: geometric data, steady flow data and unsteady flow data.

The basic geometric data used in the HEC-RAS software consists of establishing the connectivity of the river system (River system schematic); cross section data; reach lengths; energy loss coefficients (friction losses, contraction and expansion losses); and stream junction information (3). Cross sections are located at interval along streams to characterize the flow carrying capability of the stream and its adjacent flood plain.

\subsubsection{HEC-GeoRAS Model}

HEC-GeoRAS model is a set of GIS tools that used to create Fincha'a River Network including stream line, cross-section, banks, inline structure and storage area for import into HEC-RAS and generate the flood inundation data from the HEC-RAS output. The resulting flood from dam failure can be inundated with HEC-GeoRAS at available GIS data. RAS Mapper creates an inundation width and floodplain boundary from computed water surface profiles and HEC-RAS geometry.

\subsubsection{Geographic Information System (GIS)}

A geographic information system is a powerful tool used for computerized mapping and spatial analysis. Arc-GIS tools are used to create triangulated irregular network from digital elevation model of study area for creation of river network and flood inundation mapping. It is used to develop flood plain maps by using computed water surface through HEC-RAS model.

\subsubsection{HEC-RAS Model Setup}

For developing dam break analysis using hydraulic model different component of the project have been represented in the model as follows.

Table 1. Elevation-Volume curve of Fincha'a Reservoir (18).

\begin{tabular}{ll}
\hline Elevation $(\mathbf{m})$ from a.s.I & Volume $\left(\mathbf{1 0}^{\mathbf{6}} \mathbf{~ m}^{\mathbf{3}}\right)$ \\
\hline 2207 & 0 \\
2209 & 12 \\
2211 & 75 \\
2216 & 304 \\
2218 & 401 \\
2220 & 486 \\
2222 & 625 \\
\hline
\end{tabular}

\section{A. Boundary Condition}

Boundary conditions are necessary to define the upstream and downstream ends of the river system. The unsteady component of the HEC-RAS can perform subcritical, supercritical or mixed flow regime computation. In this study mixed flow regime simulation is selected in the HEC-RAS software.

\section{i. Upstream Boundary Condition}

The reservoir area upstream of the dam can either be modeled with cross-sections or by using storage area. If storage area is used, HEC-RAS uses level pool routing through the reservoir and unsteady flow routing through downstream of the dam. For this thesis study storage area is used for upstream boundary condition for dam break simulation and it is connected to upstream end of the reach. The probable maximum flood is used as lateral inflow hydrograph for the reservoir and which considered as inflow to the reservoir.

\section{ii. Downstream Boundary Condition}

For open ended river normal depth is most commonly used as downstream boundary condition. Therefore, Normal depth is used as downstream boundary condition for this thesis study. The frictional slope 0.012 is used as normal depth for downstream boundary condition.

\section{B. Initial Condition}

In addition to boundary condition the user required to enter initial condition in the HEC-RAS system as an input data at 
the beginning of the unsteady flow simulation. Initial condition consists of flow at upper end of each reach and starting elevation of storage area. The flow at upper end of each reach (initial flow) and initial storage elevation of Fincha'a reservoir is assumed to be $156 \mathrm{~m}^{3} / \mathrm{s}$ and $2222 \mathrm{~m}$ from m.s.l respectively according to rule of thumb (3).

\section{Estimating Breach Parameters}

The estimation of the breach location, size, and development time are critical in order to make accurate estimate of the outflow hydrographs and downstream inundation (10). Once the breaching parameters are estimated, the HEC-RAS can be used to compute the out flow hydrograph from the dam breach and perform downstream routing. The user is required to enter information like: failure location, failure mode, breach development time, breach shape, weir and piping coefficient and trigger mechanism into HEC-RAS model to define a dam breach.

\subsubsection{Empirical Methods}

Empirical methods are used to predict breach geometry and time to failure to estimate peak breach discharges. Since Fincha'a dam is rock fill dam, MacDonald and Langridge Monopolis (1984), Von Thun and Gillette (1990) and Froehlich (2008) are the most suitable regression equations in predicting breach parameters in order to compare different results of the three. In general, the peak discharge calculated from peak flow regression equations of these methods are used for comparison purpose with that obtained from routed peak discharge in the the HEC-RAS Model.

\section{A. Envelope Curves}

Once a breach hydrograph is computed in HEC-RAS, the computed peak flow from the model can be compared with envelope curves developed by different peak flow regression equations as a test for reasonableness (10). The hydraulic depth used for comparison over the envelope curve is observed from the model report at dam site when dam breach occurs.

\section{B. Fincha'a River and Reservoir}

Fincha'a River and reservoir are created by HEC-GeoRAS software from DEM data of that location with 42 kilometer length. The Fincha'a River and reservoirs are created through HEC-GeoRAS software is exported to HEC-RAS software for model setup and simulation purpose.

\section{Collection of Cross-Section}

Fincha'a River cross-section is collected from digital elevation model (DEM) by using HEC-GeoRAS model. The second cross-section in the pool area is required as the bounding cross section for the inline structure. The extracted cross-section from digital elevation model is used as input data for HEC-RAS model.

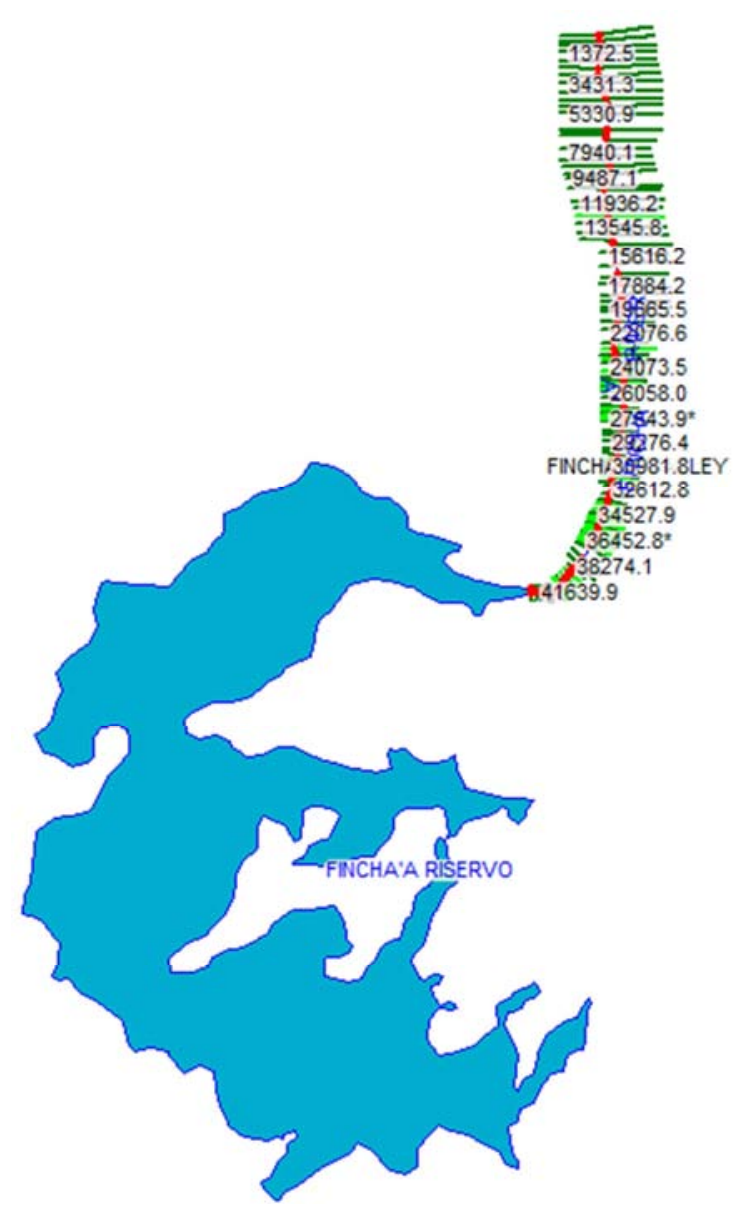

Figure 2. River Network for Fincha'a River and its reservoir coverage in HEC-RAS model.

\subsubsection{Manning Roughens Coefficient}

Roughness coefficients represent the resistance to flow and flood pains. Manning's n coefficient is used in the manning equation to calculate discharge in the open channel. The natural streams which has rocky river beds with grass banks usually steep, trees and brush along banks has manning roughness coefficient in the range of 0.03 to 0.05 (4). Since the Fincha'a river bank surface is rocky the friction resistance through the bank is low the manning roughness coefficient value is assumed to be 0.033 for bed channel and 0.046 for river banks.

\subsection{Inundation Map Preparation}

The inundation map should be developed at a scale sufficient to be used for identifying downstream inhabited areas subject to possible danger (9). GIS data required for mapping inundation is exported from HEC-RAS model to Geographic information system. The exported GIS data's are entire cross-section and maximum water surface elevation through the cross-section. Later inundation map is created by RAS mapper by using exported geographic information system data. 


\section{Results and Discussion}

\subsection{Breach Width and Time Development}

The average breach width and breach development time of the Fincha'a dam is calculated by using the information of case study of the dam through regression equation of the MacDonald and Langridge-Monopolis (1984), Von Thun and Gillette (1990) and Froehlich (2008). The average breach width and breach development time calculated by Von Thun and Gillette (1990) are $95.9 \mathrm{~m}$ and $0.58 \mathrm{hr}$ for both of overtopping and piping mode of failure. The bottom breach width of the dam which used as input for HEC-RAS model is $87 \mathrm{~m}$ for both mode of failure. Since the breach parameters calculated by Von Thun and Gillette (1990) regression equation is more reasonable than the other regression equation it is selected for Fincha'a dam break analysis.

\subsection{Overtopping Mode of Failure}

For this failure mode the most critical situation is when the reservoir is at full reservoir condition and when excess flood passes over the crest of the dam. The spillway capacity is $213 \mathrm{~m}^{3} / \mathrm{s}$ which is 34.37 times less than the maximum flood passing over the dam. Since the spillway is uncontrolled type of spillway the flow greater than its capacity flows over the dam. So, it is assumed that the dam is failed due to overtopping. The reservoir water level when dam break started will be $2222 \mathrm{~m}$ from mean sea level and the breach continues up to $2209 \mathrm{~m}$ (a.s.l).

\subsubsection{Dam Breach Statistics and Flood Hydrograph}

The maximum discharge flows out from the breached dam is $7436.8 \mathrm{~m}^{3} / \mathrm{s}\left(262784 \mathrm{ft}^{3} / \mathrm{s}\right)$ by obtaining $15.85 \mathrm{~m}(52 \mathrm{ft})$ hydraulic depth. The maximum discharge is attained at 3:00 hrs from the start of dam breach and the water is coming out with the velocity of $22.65 \mathrm{~m} / \mathrm{s}$. The hydraulic depth used to check the reality of peak discharge is calculated through the HEC-RAS model and its unit is converted from meter to $\mathrm{ft}$. The reality of this result is checked with envelope curve of experienced outflows rates from breached dam as indicated in figure 3.

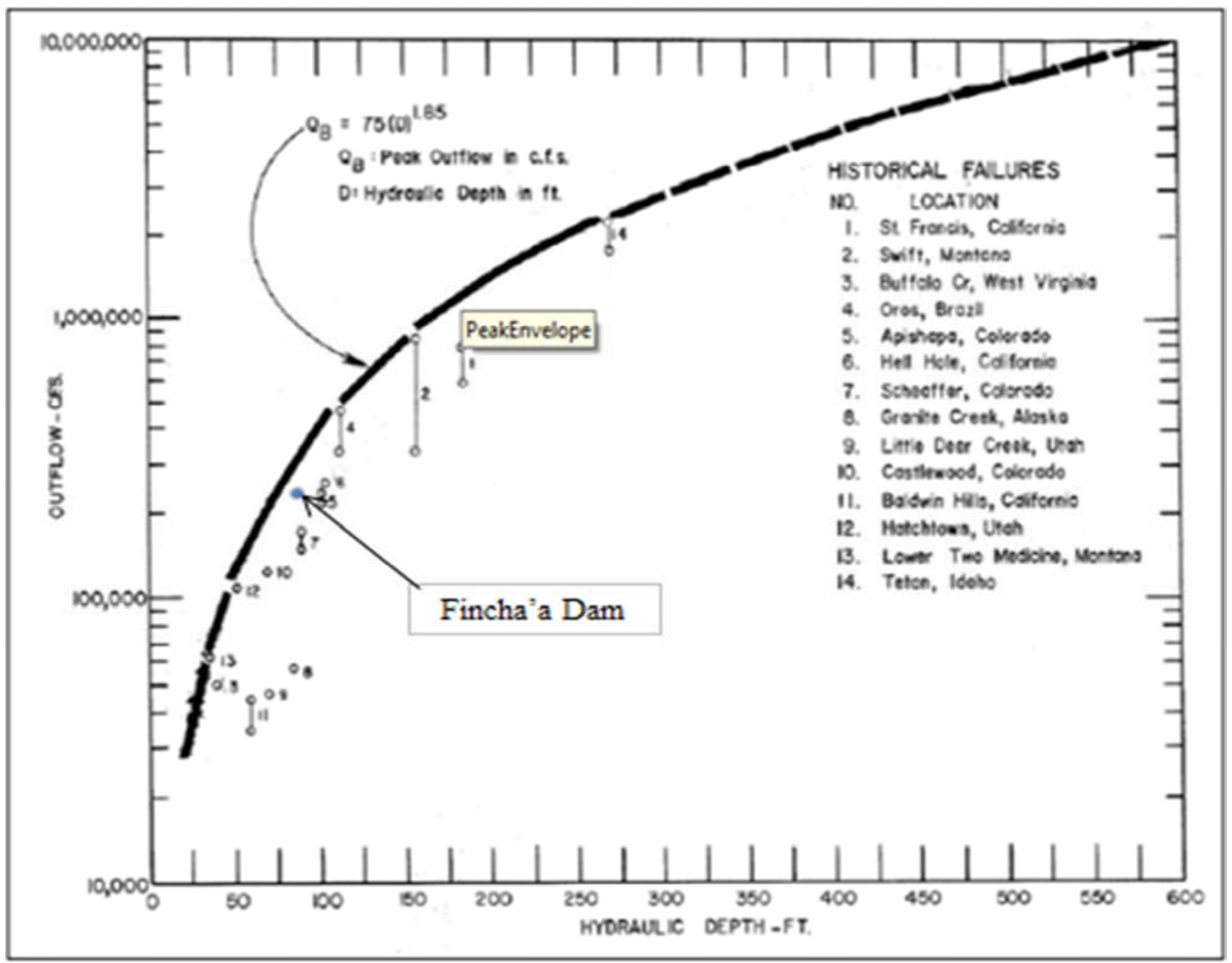

Figure 3. Location of Fincha'a dam on envelope of experienced outflow rates from breached dam by overtopping. 


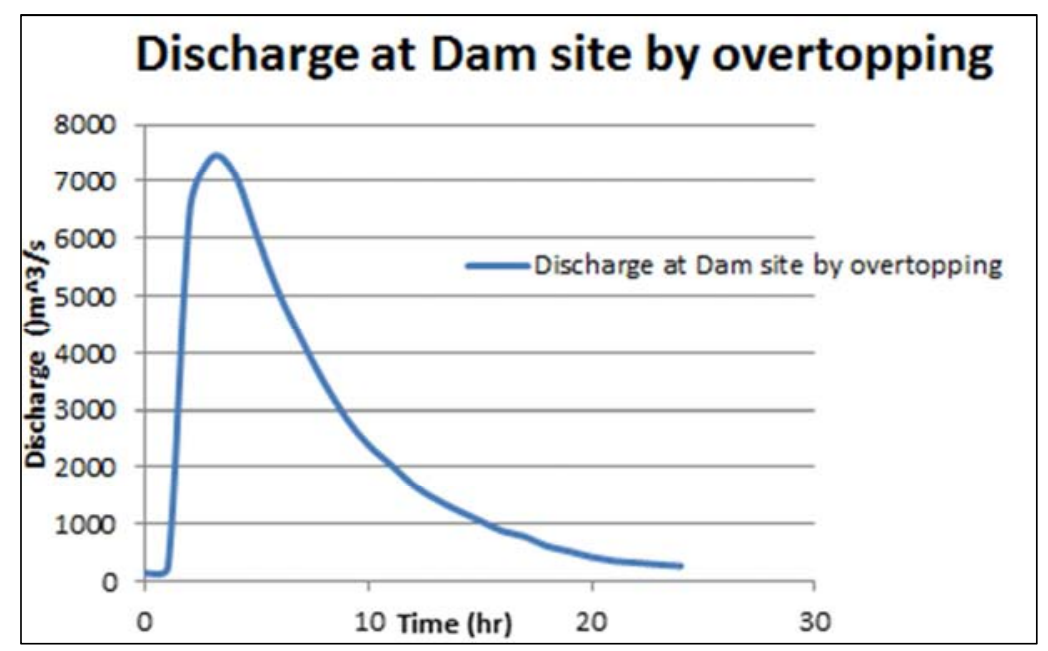

Figure 4. Flood hydrograph at Dam site by overtopping.

\subsubsection{River Cross-Section at $6.5 \mathrm{~km}$ Chainage for Overtopping Mode of Failure}

Figure 5 shows the cross section of river at $6.5 \mathrm{~km}$ with maximum water level. Generaly, the water stage is decreasing in the downstream direction. The water depth and top width over the banks at different chainage points $(6.5 \mathrm{~km}, 24.5 \mathrm{and} 42 \mathrm{~km})$ are: $3.63 \mathrm{~m}, 2.67 \mathrm{~m}, 1.74 \mathrm{~m}$ and $752.69 \mathrm{~m}, 1909.76 \mathrm{~m}, 2047.01 \mathrm{~m}$ respectively. From this number what we understand that the water depth is decreasing and top width of water is increasing along downstream direction.

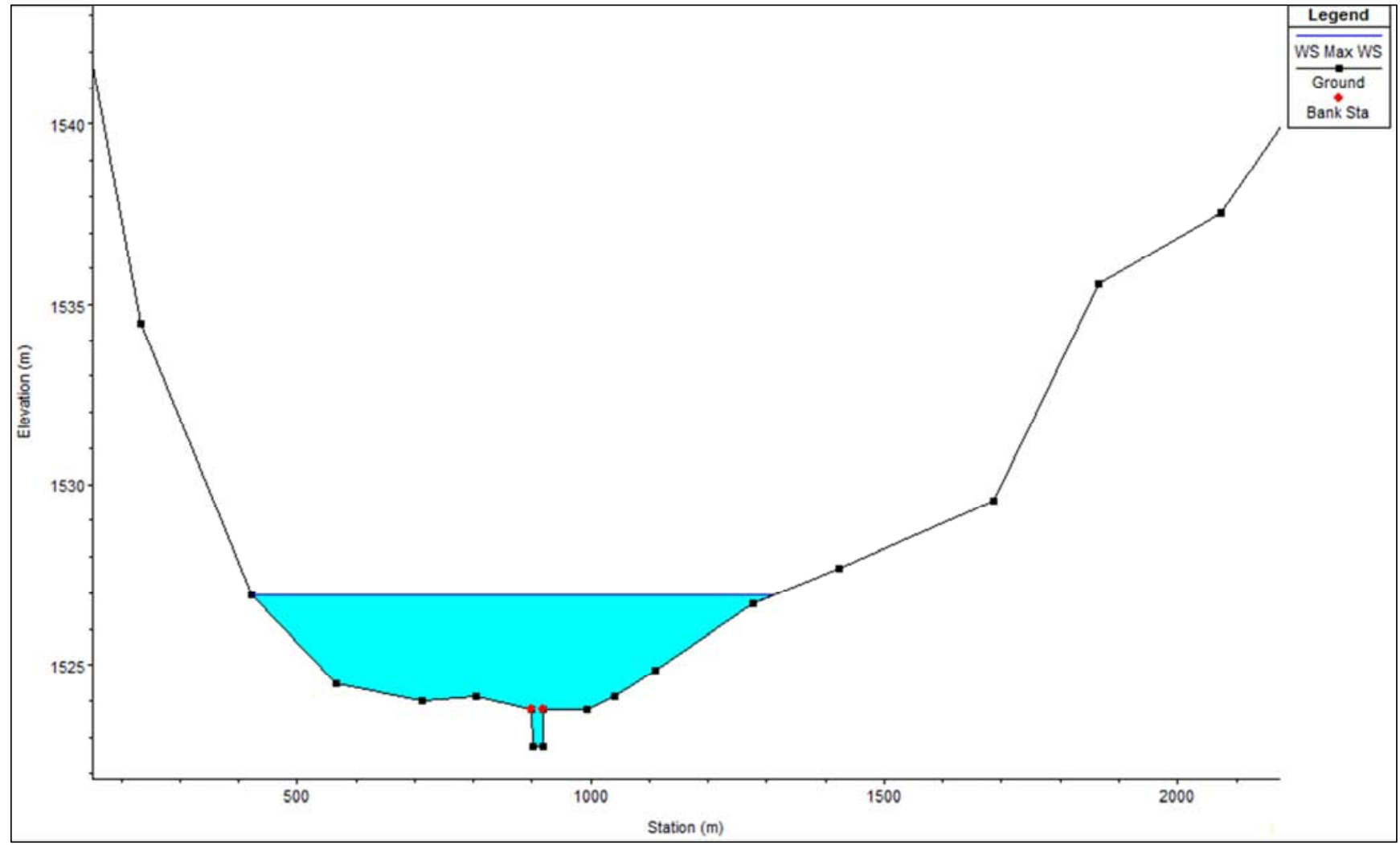

Figure 5. River cross section at $6.5 \mathrm{~km}$ from Fincha'a Dam.

\subsubsection{3-Dimensional Water Surface Profile}

The 3-Dimentional water surface profile of the fincha'a dam break along the downstream distance from the dam to end chainage and maximum water surface in all cross sections are shown in figure 6 . When water flows from uperstream to downstem the top water surface increases and the depth of flood decreases along the downstream direction. As we observe from the picture of 3-Dimentional water surface profile top water depth varies based on the shape of the valies. 


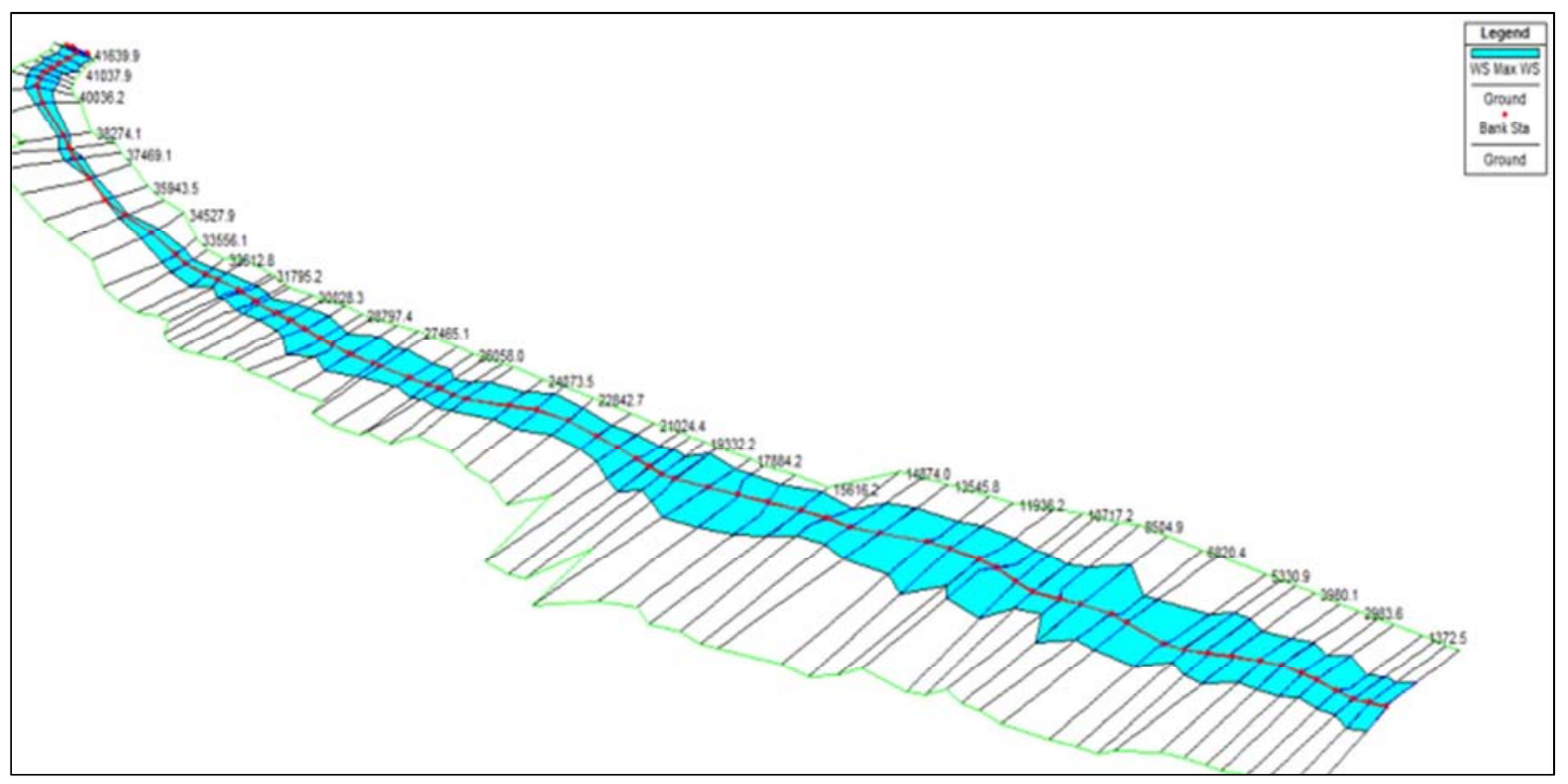

Figure 6. 3-D Water surface profile for all Fincha' a River cross-sections.

\subsubsection{Piping Failure (No PMF) Full Reservoir}

In this method the most critical condition is at normal reservoir condition. The dam breach due to piping depends on the sunny day condition. As stated under overtopping mode of failure the breach parameters used for input for HEC-RAS model are calculated by Von Thun and Gillette. At dam site the peak discharge flows out from dam breach by piping is $7241.22 \mathrm{~m}^{3} / \mathrm{s}$ at $3: 00 \mathrm{hrs}$ and it attains maximum water level $2222.01 \mathrm{~m}$. This peak flood is coming out with maximum velocity $20.94 \mathrm{~m} / \mathrm{s}$.

\subsection{Sensitive Parameters for Input Parameters in Terms of Peak Discharge and Water Level}

The sensitivity analysis of input breach parameter is undergone by changing the values of these parameters to model dam break and analyzing what is the effect of each breach parameters on discharge values and water level. So, input parameters which are considered for the sensitivity analysis are: breach time, breach width, side slope, manning's roughness coefficient and breach Weir coefficient.

\subsubsection{Effect of Breach Time}

In this section the increased and decreased breach time by $15 \%$ are compared with the calculated breach time. Breach time has more impact on peak discharge than the other breach parameters. When breach width is constant $(87 \mathrm{~m})$ as far the present study then with the $15 \%$ increase in breach time $(0.667 \mathrm{hr})$ there was decrease in peak discharge through cross section and with $15 \%$ decrease in breach time $(0.493 \mathrm{hr})$ there was increase in peak discharge.

Breach time is the time of development of breach fully in the dam structure. The more magnitude of peak discharge will result in more peak water level in the downstream. When the breach time is increased or decreased almost the same peak water level along the downstream location is observed.

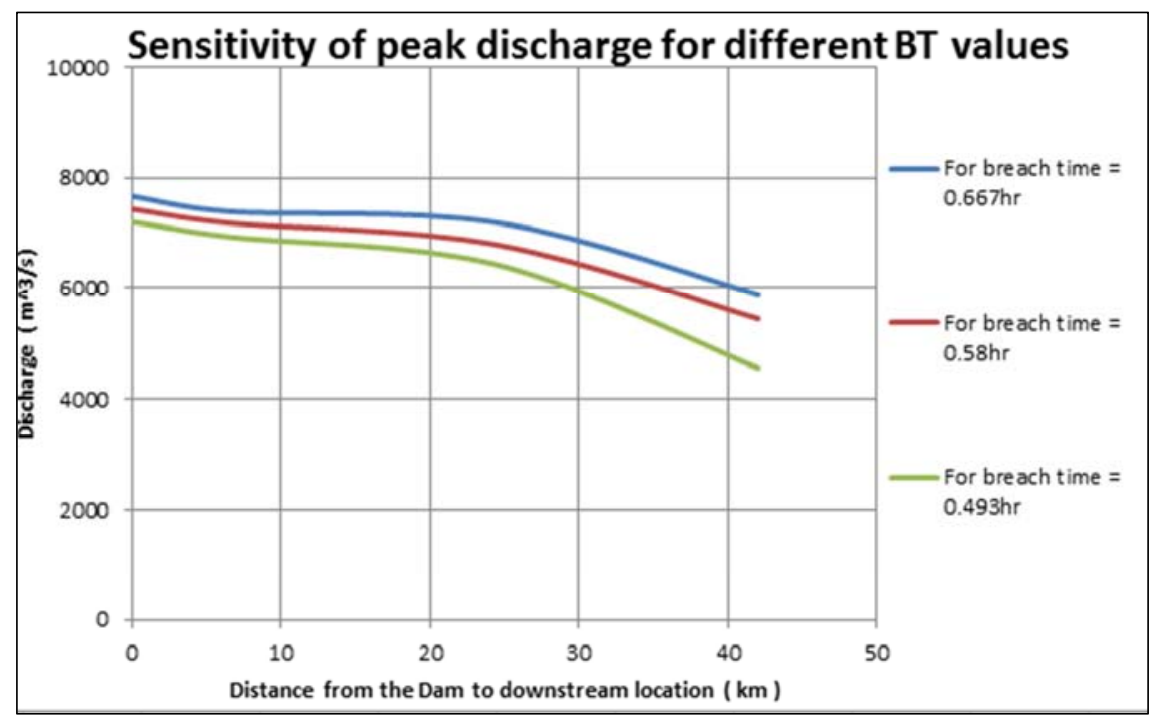

Figure 7. Sensitivity of breach time on peak discharge of Fincha'a River. 


\subsubsection{Effect of Bottom Breach Width}

In this sensitive parameter dam break model is analysed by changing breach bottom width and keeping constant the other parameters. Increasing and decreasing bottom breach width by $15 \%$ and keeping breach time constant and the results obtained is analysed as how much the breach width will affect the peak discharge and water level downstream of the valley comparing with the calculated bottom width by Von Thun and
Gillette regression equation. When bottom breach width is increased by $15 \%$ from $87 \mathrm{~m}$ to $100.05 \mathrm{~m}$ the peak discharge is increased and when it decreased by $15 \%$ then decrement of peak discharge is noticed through downstream cross section. So, with the change of bottom breach width there is slightly increment and decrement of peak discharge and almost the same peak water level along the downstream location is observed.

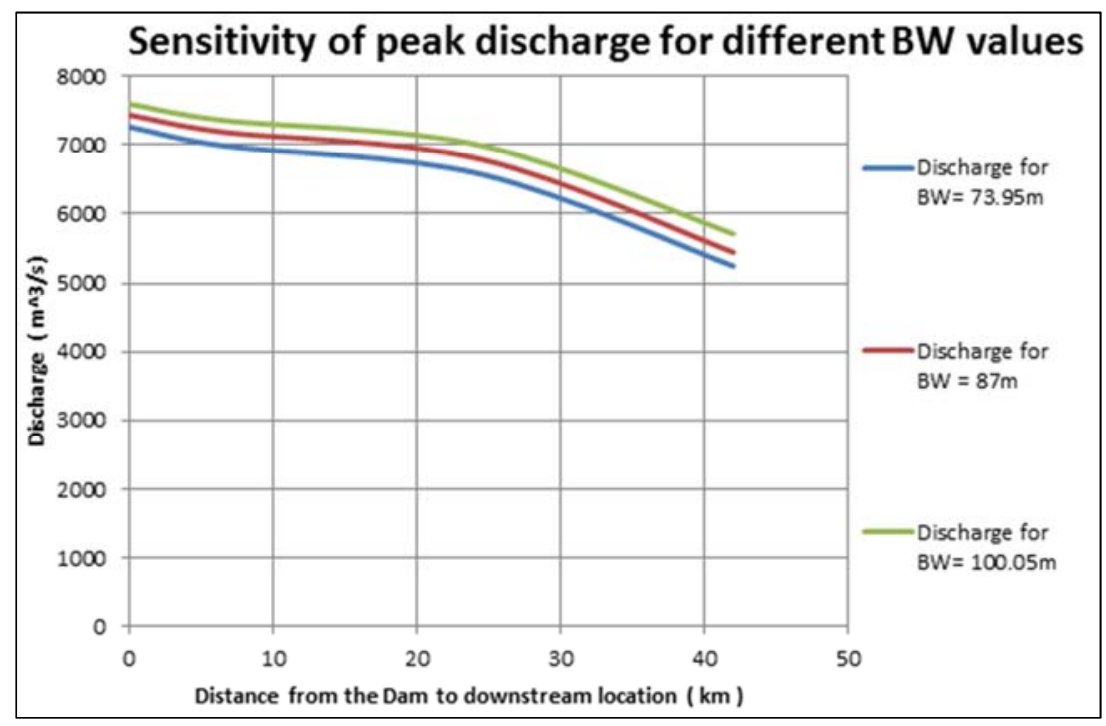

Figure 8. Sensitivity of breach width on peak discharge of Fincha'a River.

\subsubsection{Effect of Side Slope}

The side slope is the lateral slope of trapezoid of the breach section. The model is test for the side slope of $0.4,0.5$ and 0.6 (which mean decreasing and increasing side slope by $10 \%$ respectively). Results obtained from these models shows not much change in the values of discharge and water level for the downstream location. So, the sensitivity of this parameter has insignificant effect on the peak values of water level and discharge.

\subsubsection{Effect of Breach Weir Coefficient}

In this sensitive parameter dam break model is analysed by changing breach weir coefficient and keeping constant the other parameters. When breach weir coefficient is increased by $10 \%$ from $1.8 \mathrm{~m}$ to $1.98 \mathrm{~m}$ the peak discharge is slightly increased and when it decreased by $10 \%$ from $1.8 \mathrm{~m}$ to $1.62 \mathrm{~m}$ then peak discharge is slightly decreased. So, with the change of breach weir coefficient there is slightly increment and decrement of peak discharge and almost the same peak water level along the downstream location is observed.

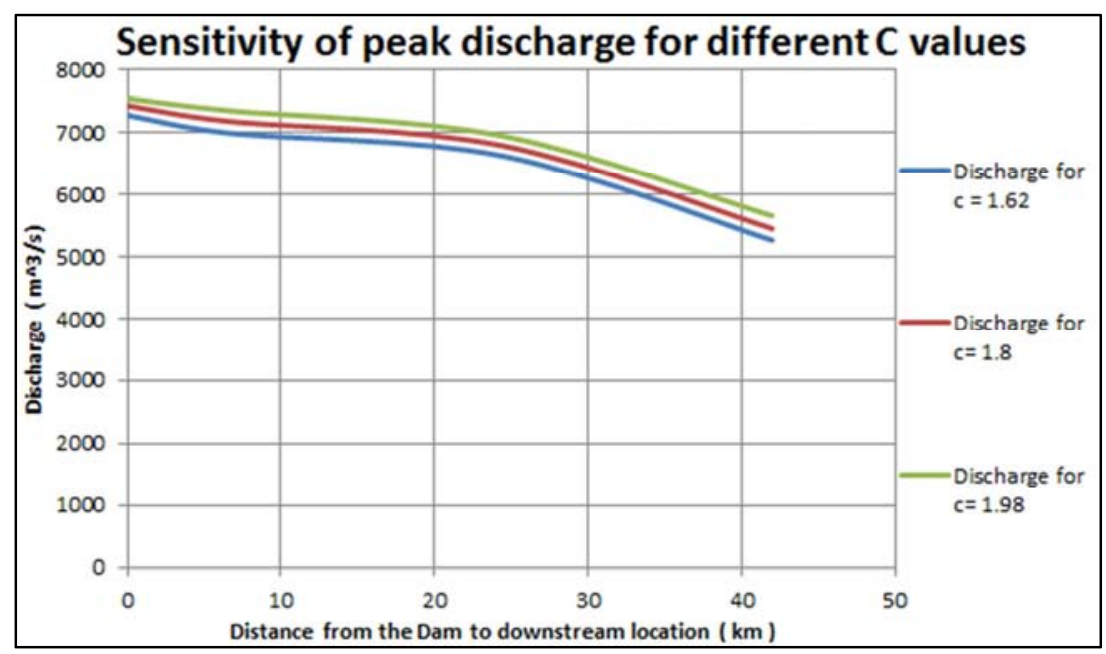

Figure 9. Sensitivity of breach wear coefficient on peak discharge of Fincha'a River. 


\subsection{Emergency Action Plan}

Development of effective emergency action plans require accurate prediction of inundation levels, top width and the time of flood wave arrival at a given location where there is infrastructure and population at risk. The arrival time for flood wave to reach the critical location along the flood path required for emergency action plans is determined by calculated velocity and water surface elevation in the HEC-RAS model. Since the peak discharge produced during dam break is high from dam site to $24.5 \mathrm{~km}$ downstream of the dam, it needs effective EAP and when we go further to downstream location the requirement of emergency action plan is significant. Figure 10 shows flood inundation map of Fincha'a dam break by overtopping mode which used for planning effective and urgent emergency action. Figure 11 and 12 shows inundation map of Fincha'a dam break by overtopping with description of risk measurement parameters. Depending on this condition dam owners and emergency management authorities give urgent protective measures. Table 2 shows the maximum water level, arrival time flood and top width of peak discharge at specified location downstream of the dam for overtopping mode of failure.

Table 2. Downstream distance over the stram line with maximum water depth, WSE, top width of flood and arrival time for overtopping mode.

\begin{tabular}{lllll}
\hline $\begin{array}{l}\text { Downstream } \\
\text { Distance }(\mathbf{k m})\end{array}$ & $\begin{array}{l}\text { Max.water } \\
\text { depth }(\mathbf{m})\end{array}$ & WSE (m) & $\begin{array}{l}\text { Top width } \\
(\mathbf{m})\end{array}$ & $\begin{array}{l}\text { Time of } \\
\text { arrival }(\mathbf{h r})\end{array}$ \\
\hline 6.5 & 4.65 & 2132.72 & 198.9 & 13 \\
24.5 & 3.62 & 1978.63 & 375.11 & 14 \\
42 & 2.5 & 1857.21 & 487.95 & 15 \\
\hline
\end{tabular}

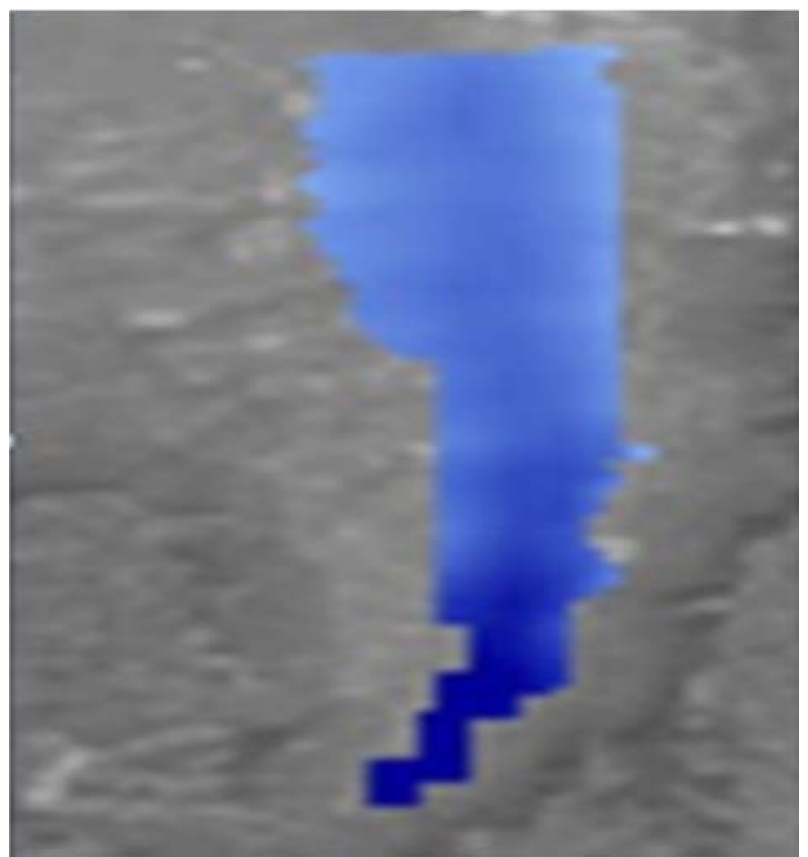

Figure 10. Flood inundation map of Fincha'a dam break by overtopping mode between the dam and $42 \mathrm{~km}$ to downstream location.

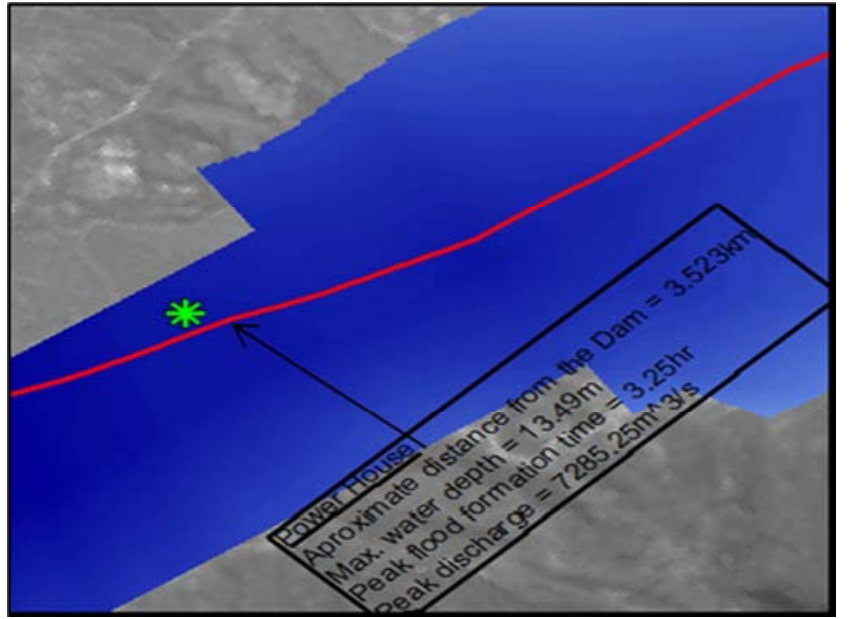

Figure 11. Flood inundation map of Fincha'a dam break by overtopping that shows flood coverage over power house.

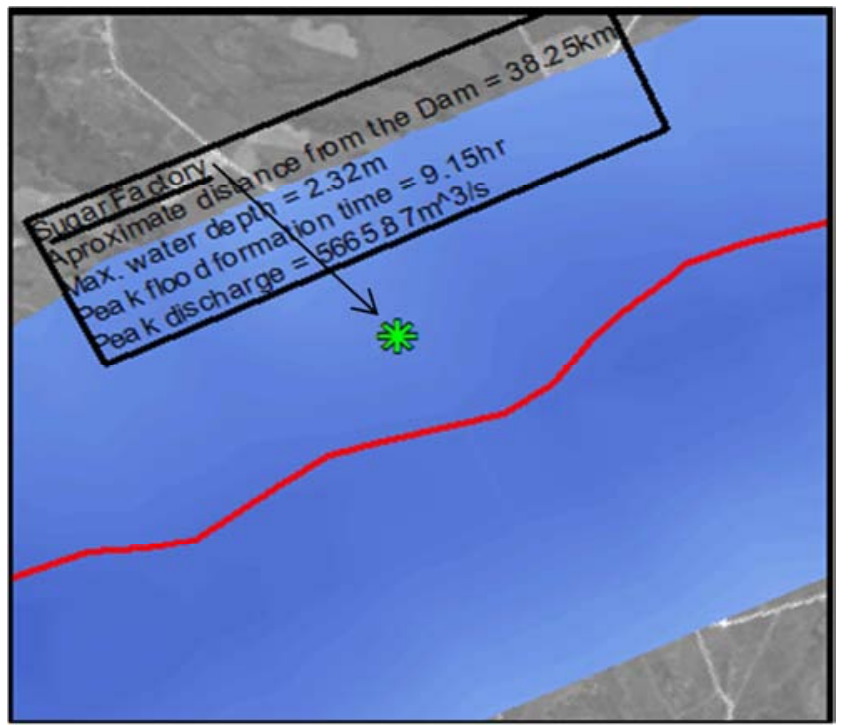

Figure 12. Flood inundation map of Fincha'a dam break by overtopping that shows flood coverage over Fincha'a sugar factory (Hagamsa town).

\section{Conclusion}

The impact of dam break in the downstream area is observed in terms of flood hydrograph, flood arrival time, water level, velocity and flood map. Further the sensitivity analysis of breach time, bottom breach width, manning roughness and breach weir coefficient is carried out for overtopping mode since the result measured in terms of flood hydrograph and water level is greater than piping mode. In accordance with sensitivity analysis, the change of breach time, bottom breach width, manning roughness and breach weir coefficient had no much influence on the downstream maximum water surface elevation. As input parameter data are different therefore the result obtained are different. So, conclusions are drawn by comparing the results as written below.

In case of Fincha'a dam the peak discharge by overtopping mode of failure is $7436.8 \mathrm{~m}^{3} / \mathrm{s}$ which is greater than peak 
discharge $7241.22 \mathrm{~m}^{3} / \mathrm{s}$ which produced by piping mode of failure.

Since the peak discharge resulted from dam break by overtopping mode of failure is greater than that of piping mode of failure that indicates the dam break by overtopping mode will develop more risk.

From sensitivity analysis the effect of breach time on discharge is more pronounced than the water lev.

The increment of water level is insignificant since the surface is flat and water flows to both sides with increasing top width.

The degree of sensitivity of breach time is more pronounced than that of other breach parameters on discharge than water level.

If the dam break unfortunately it affects the population those live downstream of the dam especially around the river. Because of this condition Finchaa dam is classified under high hazard dam for loss of human life is expected to result from the failure of the dam.

Since peak discharge and maximum water depth resulted from dam break is great for $24.5 \mathrm{~km}$ downstream of the dam, effective and urgent action plan is required for the area nearer to the river.

Developed inundation map guides the dam owners and emergency management authority to give emergency action plan for the highly affected area by flooding and used for planning future economic development area.

\section{Recommendations}

The economic development activities including power house, irrigation area and residential house downstream of the Fincha'a dam should be developed with minimum distance of $450 \mathrm{~m}$ from both river banks.

The dam owners and emergency management authority should guide communities those living and farming downstream of the dam near the river by using map of flood prone areas.

\section{References}

[1] Abdulrahman, D. Z. (2014). Case Study of the Chaq-Chaq Dam Failure: Parameter Estimation and Evaluation of Dam Breach Prediction Models. Journal of Engineering Research and Applications, 109-116.

[2] Altinakar, M. (2008). Modeling Tools for Dam Break Analysis. Mississippi: National Center for computational Hydroscience and Engineering.

[3] Brunner, G. W. (2010). HEC-RAS, River Analysis System Hydraulic Reference Manual. United State of America: U.S Army Corps of Engineer.

[4] Chow, V. T. (1959). open channel hydraulics. Tokyo: kogakusha campany.

[5] Colorado Dam Safety Branch. (2010). Guidilines for Dam Break Analysis. Colorado: Colorado Division of Water
Resource.

[6] Corporation, E. E. (2004). Facts about power plant in Ethiopia. Addis Ababa: Ethiopian Electric and Power Company.

[7] Engineer, W. R. (March 27-29, 2007). HEC-RAS DAM BREAK MODELING OF. Georgia Water Resources Conference (pp. 1-3). Atlanta: University of Georgia.

[8] FEMA. (2013, july). Federal guidelines for innundation mapping of flood risks associated with Dam incidents and failures. FEMA, p-946.

[9] Fread, D. L. (2011). Guidelines for developing an Emergency Action Plan. united state: Department of Environmental protetion.

[10] G. B. (2014). Using HEC-RAS for Dam break studies. United State: Institute of water Resource Hydrologic Engineering center (CEIWR-HEC).

[11] Gee, D. (2008). Comparison of breach parameter estimators. U.S.A: Corps of Engineers Hydrologic Engineering Center, 609 2nd st.,, Davis, CA, 95616.

[12] Kamanbedast, A., \& Bryanvand, R. (2014). Effects of Dam Break on Downstream Lands Using Gis and Hec-Ras (Case. Advances in Environmental Biology, 2314-2321.

[13] Libraries, U. o. (2012). Introduction to GIS. USA: U.S. Government Information, Maps \& GIS Services.

[14] Natale. E. (2009). Dam Break Analysis. Massachusetts Institute of Technology, Civil and Environmental Engineering. Chilean Patagonia: MIT.

[15] Sachin. (2014, may). Dam Break Analysis Using Mike11. Master Thesis, 11-13.

[16] Safety, D. o. (2009). Guidelines for Developping an Emergency Action Plan. Pennsylvania: Pennsylvania Emergency Management Agency.

[17] Shahraki, A., Zadbar, A., Motevalli, M., \& Aghajani, F. (2012). Modelling of Earth Dam Break with SMPDBK Case Study: Bidekan Earth Dam. World Applied Science, 376-386.

[18] Source Ministry of Water, Irrigation and Energy. (1973). design of fincha'a dam fesibility study. Addis abeba:.

[19] Steininger, A. (2014). Dam Overtopping and Flood Routing. Colorado: Colorado State Universiyt Department of Civil and Environmental Engineering.

[20] Sterk, B. T. (2008, Feburary ). Hydropower-Induced Land Use Change in Fincha'a Watershed, Analysis and Impacts. Mountain Reserch and Development, 28 (1): 72-80.2008, 2,73.

[21] Tefera, B. (2006). Environmental and social-economoic Changes indused by a reservoir Fincha'a Watershed. Tropical Resource Mangement, 3.

[22] Wahl, T. L. (1998). Prediction of Embankment Dam Breach Parameters. u.s: DSO-98-004.

[23] Xiong, Y. (. (2011, march 28). A Dam Break Analysis Using HEC-RAS. Journal of Water Resource and Protection, 370-379. 